\title{
Looking beneath the Surface: The Cell Death Pathway of Fas/APO-1 (CD95)
}

\author{
Ben Z. Stanger \\ Department of Genetics, Harvard Medical School and Howard Hughes \\ Medical Institute, Boston, Massachusetts, U.S.A.
}

Summary: The biochemical basis of programmed cell death is poorly understood in mammals. The cell surface receptor Fas/APO-1 (CD95) is one molecule known to be central to a number of mammalian cell death processes. Several studies in the past year have led to insights about the role of Fas/APO-1 in vivo and have also given some clues about the biochemical components of the Fas/APO-1 death pathway. This article reviews those studies and discuss models of Fas/APO-1 signaling and function.

Background: Cell death occurs as a normal process in a wide variety of developmental and homeostatic contexts in metazoan organisms (1); it represents the timely and appropriate fate for many or even the majority of cells born in certain organ systems. Despite the importance and ubiquitous nature of such physiologic, or "programmed", cell death, little is known about the molecular events that mediate this process. That a conserved biochemical pathway exists is suggested by the observation that programmed cell death is almost always accompanied by a consistent set of morphologic changes, an appearance known as apoptosis (2).

The identification of the genes that control programmed cell death in higher eukaryotes has been hampered by several inherent difficulties. First, the genetic tools so useful in dissecting cell death pathways in Caenorhabditis elegans (3) and Drosophila (4) have not been available in higher eukaryotes. Second, the death-inducing properties of such genes makes genetic selection an impractical means of identification. Third, it appears that many cell death genes are constitutively expressed and present in an inactive form (5), making it unlikely that they could be discovered by techniques relying upon differential gene expression. Finally, genes identified by virtue of an ability to induce death when overexpressed must be subjected to rigorous criteria to determine whether the cell death is of physiologic importance, since it is likely that overexpression of certain proteins may lead to toxic effects that are distinct from the in vivo roles of those proteins.

Two approaches to date have yielded the most information about cell death processes: (i) identification of cell death genes by classical genetic means coupled with characterization of their mammalian homologs and (ii) screening for proteins capable of inducing cell death directly in mammalian cells. The Fas antigen/APO- 1 is an example of a protein discovered using the latter approach, as it was first discovered as an inducer of cell death and later shown to be necessary and sufficient for certain programmed deaths in vivo. More recent studies have connected Fas to elements of cell death pathways in other species. It has been proposed that Fas is related to the Drosophila cell death protein Reaper, and that in signaling cell death Fas relies upon a relative of the $C$. elegans cell death protein CED-3. Fas may therefore represent an evolutionarily conserved component of a universal cell death pathway.

\section{IN VIVO FUNCTIONS OF FAS AND ITS ROLE IN HUMAN DISEASE}

Fas/APO-1 was identified independently by two groups performing monoclonal antibody screening. The antibodies were chosen for analysis

Address correspondence and reprint requests to: Ben $\mathrm{Z}$. Stanger, Harvard Medical School, Department of Genetics, 200 Longwood Avenue, Boston, MA 02115. based on the unusual property of being able to induce death in a wide variety of cell types. The cell surface molecule recognized by these antibodies was named APO-1 by one group (6), and Fas antigen by the other (7); subsequent cloning revealed Fas and APO- 1 to be derived from the same gene $(8,9)$. This gene encodes a transmembrane protein of about $45 \mathrm{kD}$ that is widely expressed (although more abundant in certain tis- 
sues such as thymus, lung, heart, and liver) and bears a strong similarity in its extracellular domain to members of the tumor necrosis factor family of receptors (TNF-Rs). This family includes the p75 nerve growth factor receptor, CD40, CD30, CD27, 4-1BB, and OX40 (among others) and is characterized by a cysteine-rich extracellular repeat motif; not surprisingly, the ligands for these receptors are also remarkably well conserved (reviewed in Ref. 10). At first glance, the cytoplasmic domain of Fas/APO-1 had no observed similarity to proteins outside of this family, although a relationship to several other proteins has now been appreciated (described below). Among members of the family, Fas/APO- 1 bears the greatest resemblance $151 \%$ similarity) to the TNF-R type l (TNF-R l; p55 TNF-R) over a 45-amino acid stretch (8). Many of the models of Fas/APO-1 signaling have therefore been based on known components of the TNF-R1 pathway.

Mutations in the fas gene are responsible for the recessive lymphoproliferation (lpr) phenotype in mice (11). lpr mice develop a progressive lymphadenopathy and immune complex syndrome that resembles the human autoimmune disease systemic lupus erythematosus. Two mutations can lead to the phenotype: an insertion, which prevents normal processing of precursor RNA, and a point mutation in the cytoplasmic domain that renders Fas/APO-1 incapable of transmitting the death signal. When the ligand for Fas/APO-1 was cloned (FasL [12]), a mutation in this gene was found to cause the phenotype seen in the mouse mutant gld, a non-allelic phenocopy of $l p r(13,14)$. These studies demonstrated that both the receptor and its ligand are needed for the elimination of immune cells capable of recognizing self-antigen-a process known as "tolerance" to self-antigen.

How do mutations in these cell death genes lead to autoimmune disease? The answer to this question may rest with alterations in the process of activation-induced cell death (AICD), which occurs when certain $\mathrm{T}$ cells are triggered through the T-cell receptor (15). In vivo, AICD may serve to clear the circulation of mature autoimmune $T$ cells that have escaped earlier selection and normal activated $T$ cells that have already done their job, both of which pose a potential hazard to the organism. The abnormal $\mathrm{T}$ cells of $l p r$ mice arise from a defect in elimination at a mature developmental stage (16), and indeed, activated T cells from $l p r$ and gld mice are unable to undergo AICD (17). Soluble Fas/APO-1 can block AICD in a number of T-cell lines (18-20), demonstrating that Fas/APO-1 is directly responsible for the death of these mature T cells. Fas/APO-1 is also required for the elimination of $B$ cells that have become nonspecifically activated by a process known as "bystander" activation (21), as well as the specific elimination (clonal deletion) of selfreactive $B$ cells from the periphery (22). These results indicate that autoantibody production in lpr animals (23) may be directly attributable to abnormal B-cell activity rather than to a secondary effect orchestrated by autoimmune $\mathrm{T}$ cells.

In addition to its role in maintaining tolerance, Fas/APO-1 is required for cytotoxic T cells (CTLs) to kill their targets, forming an auxilliary pathway to the well characterized granule exocytosis pathway (reviewed in Ref. 24). It is not currently known which settings in vivo utilize the Fas/APO-1 pathway versus the granule exocytosis pathway for CTL activity. Whether the participation of Fas/APO-1 in CTL killing is also responsible in part for the $l p r$ autoimmune phenotype likewise remains to be determined. In addition, Fas is capable of triggering hepatocyte cell death (25), and mice bearing a targeted mutation (which renders them true nulls for fas) develop liver hyperplasia (26), implying that Fas may play a role in liver homeostasis. (See also the article by Leist et al. in this issue [27] suggesting that the Fas-mediated death of hepatocytes does not depend upon the expression of TNF-R l).

Thus, Fas/APO- 1 is required for at least two physiologic processes in vivo: the maintenance of tolerance to self-antigen and cytotoxic T-cell activity. The range of human disease attributable to mutations in fas is just beginning to be discovered. For example, a subset of lupus patients synthesize elevated levels of a variant Fas antigen lacking a transmembrane domain (28). This variant protein may interfere with Fas/FasL interactions, and could play a role in the pathogenesis of autoimmune disease by blocking autoreactive cell death. Recent studies suggest that mutations in human Fas are associated with lymphoproliferative syndromes that appear to be the human equivalents of the murine lpr phenotype $(29,30)$. The Fas system also has potential applications in certain clinical situations; in particular, overexpression of FasL on donor tissues may be an effective inhibitor of post-transplantation graft rejection (31).

Most intriguing, however, is the prospect that Fas/APO-1 may participate in the pathogenesis of disease caused by human immunodefi- 
ciency virus (HIV). $\mathrm{CD}^{+}$lymphocytes from asymptomatic HIV-infected patients are abnormally susceptible to AICD (32), a process now known to be regulated by Fas and its ligand (see above). More recent studies have demonstrated that $\mathrm{T}$ cells from HIV-infected individuals are more sensitive to Fas-induced killing than those of normal individuals (33), and that the HIV proteins Tat and gp 120 can directly sensitize cells to the effects of Fas/APO-1 (34). A cell death pathway involving Fas/APO-1 may therefore underlie the T-cell depletion seen in AIDS, making the elucidation of this pathway all the more important.

\section{EVIDENCE THAT FAS/APO-1 SELF-ASSOCIATES}

The sequence of the Fas/APO-1 cytoplasmic domain contains no obvious clues about the mechanism of cell killing; in particular, the intracellular portion of Fas/APO-1 has no recognizable kinase or phosphatase domains, no $\mathrm{SH} 2$ or $\mathrm{SH} 3$ docking motifs, nor homology to other membrane proteins involved in regulating cell death (e.g., $b c l-2$ ). However, as mentioned above, the Fas/APO-1 cytoplasmic domain does have a region with significant similarity to the TNF-R 1 cytoplasmic domain. On the basis of this homology, deletion and mutation analyses were performed which showed that this homology region is important for the ability of both molecules to induce cell death (35), and gave rise to the name "death domain" to refer to this conserved region (36). It was hypothesized that the death domain may serve as a protein-protein interaction motif, with the attractive possibility that both Fas/APO-1 and TNF-Rl may signal cell death through their interaction with a common intracellular ligand.

A model soon developed that held Fas/ APO-1 aggregation as the principle means of receptor activation (Fig. 1A). Studies of receptor tyrosine kinases had already given precedent to the notion that receptor signaling may occur through aggregation and subsequent association with cytoplasmic proteins through interaction domains (reviewed in Ref. 37). Several observations suggested that aggregation is likewise important in Fas/APO-1 signaling. Dhein et al. (38) demonstrated that crosslinking is required for transmission of the Fas/APO-1 death signal, such that $\mathrm{F}\left(\mathrm{ab}^{\prime}\right)_{2}$ preparations of anti-Fas/APO-1 antibodies are unable to induce apoptosis unless an
anti-Ig $\mathrm{F}\left(\mathrm{ab}^{\prime}\right)_{2}$ crosslinking antibody is also present. The crystal structure of ligand-bound TNF-R1 extracellular domain showed that this complex exists as a trimer (39). Moreover, immunofluorescence studies of transiently transfected cells expressing either wild-type Fas/ APO-1 or an interleukin 4 receptor (IL-4R) Fas chimera have shown a punctate membrane staining pattern as though receptor clustering occurs even in the absence of ligand (Stanger and Leder, unpublished results).

More recently, studies using chimeric receptors have demonstrated that the extracellular domains of CD40 (40), the erythropoietin receptor (41), and IL-4R (Stanger and Leder, unpublished results), can all be substituted for the extracellular domain of Fas/APO-1 without any loss in death-inducing activity. These studies suggest that the extracellular domain serves merely to aggregate Fas/APO-1 intracellular domains when ligand is present. Although the possibility remains that ligand binding may lead to other, more complex, alterations in receptor conformation, the aggregation model remains the simplest explanation for preserved function with multiple distinct extracellular domains.

\section{THE DEATH DOMAIN AS A MEDIATOR OF PROTEIN- PROTEIN INTERACTIONS}

Modular binding domains such as the Src and Pleckstrin homology domains are utilized in many signal transduction proteins, and the death domain may represent an analogous domain in cell death signal transduction. Binding modules provide not only a convenient framework for interactions between various proteins, but can also determine the specificity of their interactions. Unfortunately, there is little direct evidence to support the Fas aggregation hypothesis. Attempts to document Fas/APO-1 self-association by co-immunoprecipitation from cells have been disappointing. The best evidence to date for an interaction comes from the yeast two hybrid method (42). Experiments utilizing this system have shown a capacity for self-association of the cytoplasmic domains of both Fas/APO-1 $(43,44)$ and TNF-Rl $(43,45)$, as well as a weak association between the cytoplasmic domains of the two receptors (43). The ability of a death domain to self-associate has also been demonstrated in vitro, as fusion proteins consisting of the cyto- 

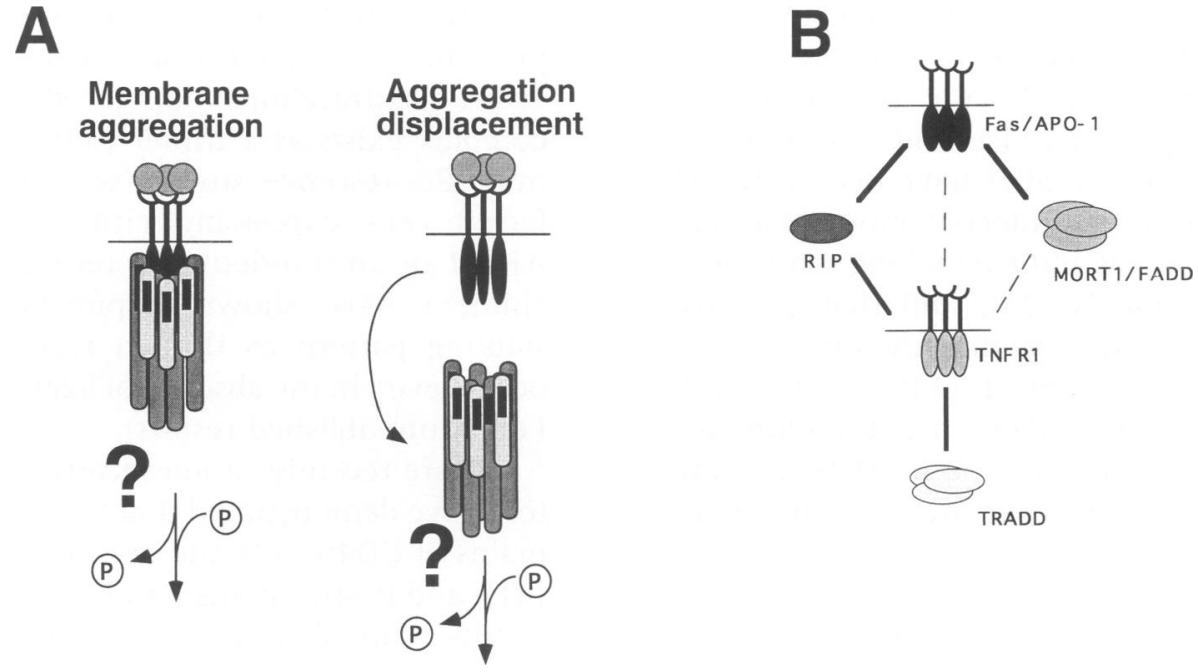

FIG. 1. Fas/APO-1-interacting proteins

(A) Models of membrane proximal events in Fas/APO-1 signaling. On the left, Fas ligand binding has caused the aggregation of Fas/APO-1 cytoplasmic domains and/or the heterotypic association of other death domain-containing proteins (e.g., RIP, MORTI/FADD). Other Fas-associated proteins or modifiers of the Fas/APO-1 signal (e.g., FAP-1, HCP) may also be components of the complex, and may serve in trans to activate the signaling cascade. On the right, this complex had existed preformed and upon ligand binding was displaced from the membrane by the homotypic association of Fas/APO-1 death domains. The complex can now freely act in the cytoplasm. (B) Interactions between Fas- and TNF-Rl-associated proteins. Known interactions are shown with solid lines, while interactions for which there is some evidence are shown with dotted lines. Proteins for which self-association has been demonstrated are indicated as trimers. Degree of shading represents the extent of amino acid identity with the Fas/APO- 1 death domain (the order is: RIP $>$ TNF-R1 $=$ MORT1/FADD $>$ TRADD).

plasmic domain of TNF-Rl fused to the E. coli maltose binding protein or glutathione-S-transferase are capable of binding to each other (43).

Additional support for the notion that death domains can mediate protein oligomerization comes from the finding that two proteins capable of interacting with the Fas/APO-1 cytoplasmic domain (MORT1/FADD and RIP) and one capable of interacting with the TNF-R 1 cytoplasmic domain (TRADD) all contain death domains $(44,46-48)$. Although extensive pairwise testsof-association have not been performed with death domain-containing proteins, there is some specificity to their binding: the death domaincontaining proteins identified so far are capable of interacting with some but not all other members of the family (Fig. 1B).

Both MORT1/FADD and RIP are incapable of binding a mutant Fas/APO-1 bearing a mutation analogous to the inactivating point mutation in the $l p r$ death domain. Moreover, MORT1/FADD and RIP can bind to a mutant Fas/APO-1 missing the $15 \mathrm{C}$-terminal amino acids, which are not required for Fas/APO-1 to induce cell death (35). However, these novel proteins do not bind to Fas mutants bearing more extensive C-terminal deletions which block Fas/APO-1 signaling $(44,48)$, indicating that their interactions bear relevance to signaling in vivo. Finally, TRADD, MORT1/ FADD, and RIP are all capable of inducing cell death upon transient overexpression, making them strong candidates for proximal signaling components of the Fas and/or TNF-RI death pathway.

However, the most convincing evidence of a role for these proteins in Fas/APO-1 signaling has yet to be obtained: (i) do MORTI/FADD, RIP, and TRADD interact with Fas or TNF-Rl physiologically and if so under what conditions (e.g., ligand binding); and (ii) does disruption of any of these candidate genes lead to a block in the signal transmitted by either receptor? It has recently been proposed that the cytoplasmic domains of Fas/APO- 1 and TNF-Rl (and by extension these three newly identified death domain-containing proteins) represent mammalian homologs of the Drosophila Reaper protein (49). The reaper gene was identified through a genetic screen for mutants deficient in cell death during embryogenesis, and seems to be both necessary and sufficient 
for much of the cell death during Drosophila development $(50)$. Close inspection of the 65amino acid Reaper polypeptide has revealed a limited degree of similarity with the death domain-containing proteins of mammals $(49,51)$, raising the possibility that Reaper-like sequences have been conserved and incorporated into various proteins as a death cassette. Insertion of this death domain cassette into transmembrane proteins may have permitted ligand-regulated cell death induction; by inducing aggregation, the death domain of Fas/APO-1 or TNF-R1 may serve as a nucleus for the association of other Reaper-like molecules that transmit the actual death signal.

\section{MODELS OF KINASE AND PHOSPHATASE INVOLVEMENT}

The events following Fas receptor crosslinking are still not known, but it appears at least that signals generated by Fas/APO-1 ligation do not proceed directly to the nucleus, since cells enucleated with cytochalasin B still undergo cytoplasmic changes characteristic of apoptosis $(52,53)$. Moreover, a number of post-receptor processes modulate Fas/APO-1 signaling, as cells expressing high cell surface levels of Fas may vary in their susceptibility to anti-Fas depending upon the degree of T-cell activation $(54,55)$ or with the nature of B-cell co-stimulation (21).

Nevertheless, several scenarios can be envisioned for the steps following Fas/APO-1 ligation. One model is that Fas/APO-1 signaling is achieved through the action of kinases and/or phosphatases. Kinases participate in signaling by several membrane receptors that are themselves enzymatically inert, including JAK kinases in cytokine receptor signaling and Src-family kinases in antigen receptor signaling (56). TNF-Rl acts through a kinase cascade that includes a sphingomyelinase-induced ceremide intermediate (reviewed in Ref. 57) and a family of kinases capable of phosphorylating c-Jun - the stress activated kinases $(58,59)$. Although the participation of these protein kinases in TNF-R signaling is well established, it is unclear whether they are relevant to Fas signaling. In addition, the death domain of TNF-Rl itself has been shown to interact with a Ser/Thr protein kinase $(60,61)$.

Fas ligation results in the rapid tyrosine phosphorylation of many cellular proteins, and the tyrosine kinase inhibitor herbimycin $\mathrm{A}$ has been shown to interfere with DNA fragmentation and cell death in Jurkat cells (62), although protection was not seen in L929 cells treated with herbimycin A (63). At least two proteins known to interact with Fas/APO-1 in a yeast two-hybrid assay are apparently involved in the transfer of phosphate groups: RIP, which encodes a putative protein kinase (44) and FAP-1, which encodes a protein phosphatase (64). The kinase domain of RIP contains regions of similarity to both Ser/Thr and Tyr kinases, an unusual feature among kinases which it shares with the soybean kinase GmPK6 (65). In the subdomains that appear to mediate hydroxyamino acid recognition (66), RIP resembles a Ser/Thr kinase, while in the framework residues outside the active site, RIP is more similar to Tyr kinases. However, the kinase domain of RIP is clearly not needed for its ability to induce cell death in transfected cells, since deletion mutants lacking the catalytic domain can still kill cells (44).

FAP- 1 is capable of binding to the C-terminal 15 amino acids of Fas/APO-1, a region previously shown to inhibit Fas signaling (35). FAP-1 is identical to a portion of PTP-BAS, a tyrosine phosphatase cloned from human basophils that is expressed in many tissues (67). The interaction is mediated by one of the GLGF repeats of PTPBAS, in a domain that appears to be important for regulation of phosphatase activity. High levels of FAP-1 expression are correlated with resistance to Fas-induced killing in several cell lines, and FAP-1 overexpression can render Jurkat cells Fas-resistant in an expression-dependent manner, consistent with an inhibitory role for FAP-1 in Fas signaling (64). The possibility that RIP and FAP-1 may act antagonistically on the same substrate remains to be explored.

Nevertheless, a simple model of pro-apoptotic kinases and anti-apoptotic phosphatases does not accurately represent Fas/APO-1 signaling. Instead, signaling is likely to be regulated by a dynamic site-specific crosstalk between kinases and phosphatases. This complexity is already apparent in the role that phosphatases seem to have in Fas/APO-1 signaling. In contrast to the FAP-1 phosphatase, which has an inhibitory effect on Fas/APO-1 killing, other phosphatases appear to promote or mediate the Fas death signal, since phosphatase inhibitors can block Fasmediated death $(63,68)$. The hematopoietic cell protein tyrosine phosphatase (HCP) is a candidate for such an apoptotic phosphatase. Its expression is positively correlated with Fas sensitivity in a number of cell lines and overexpres- 
sion of HCP can render a Fas-resistant cell line sensitive to anti-Fas antibodies (68). Moreover, an autoimmune phenotype is seen in mice of the strain motheaten, which have mutations in the HCP gene (69).

Other membrane-proximal pathways may be used to transduce the Fas/APO-1 death signal. Fas/APO-1 ligation causes the rapid activation of sphingomyelinase, which makes ceramide by cleaving the phosphocholine-linked sphingoid fatty acid sphingomyelin $(70,71)$. Sphingomyelinase and ceramide are themselves pro-apoptotic, leading to cell death and DNA fragmentation within 3 to $6 \mathrm{hr}(72,73)$. However, the role of this fatty acid intermediate in Fas/APO-1 signal transduction is still undetermined, and at least one study failed to find ceramide release during Fas- or TNF-induced killing of the breast carcinoma line MCF7 (74). In addition, overexpression of a ras dominant negative mutant or microinjection of anti-Ras antibodies was able to partially block cell death, suggesting that part of the Fas/APO-1 pathway utilizes Ras (75). Most Tyr phosphorylation events following Fas ligation on Jurkat cells are not altered by blocking Ras, although overexpression of the dominant negative Ras did inhibit the tyrosine phosphorylation of one $\sim 97-\mathrm{kD}$ protein; notably, this protein has the same molecular weight as ceramideactivated protein kinase (76).

Thus, many possibilities still exist for the initial steps in Fas/APO-1 signaling, including death-inducing proteins capable of interacting directly with Fas, and complex interactions among kinases, phosphatases, fatty acids, and possibly Ras. Furthermore, the observation that under certain circumstances Fas can transmit activation as well as death signals (77-80) highlights the regulatory complexity that is likely to underly Fas/APO-1 signaling.

\section{CYSTEINE PROTEASES}

One guiding hypothesis in cell death research has been the prospect (and hope) that an evolutionarily conserved final common pathway may serve as the convergence point for multiple cell death stimuli $(81,82)$. Two genes identified through mutant analysis and known to be required for most programmed cell deaths in $C$. elegans, ced-3 and ced-4 (3), have been obvious candidates for such a process. The ced-3 gene has been cloned (83) and encodes a protein which resembles the mammalian interleukin $1 \beta$-con- verting enzyme (ICE) (84), a cysteine protease that cleaves after Asp residues. ICE belongs to a family of cysteine proteases that includes Nedd2/ ICH-1, CPP32, and ICH-2 (reviewed recently in Ref. 85). Transient overexpression of most members of the family induces cell death (Ref. 86 and those above). Of note, the cytotoxic granule protein Fragmentin 2/granzyme B is also a protease with Asp specificity (87). Fragmentin 2 is capable of inducing cell death (88), and appears to do so by cleaving CPP32 (89).

Strong support for the notion that a cysteine protease is required for Fas/APO-1 killing came from the finding that both the cowpox-encoded ICE-inhibitor CrmA and/or a noncleavable IL- $1 \beta$ transition state analogue (Ac-Tyr-Val-Ala-Aspaldehyde) could prevent Fas-induced apoptosis (90-92). Several approaches have been taken to determine which protease(s) are responsible, including an in vitro system in which many of the morphologic and biochemical hallmarks of apoptosis are preserved (93). One such hallmark is the cleavage by an Asp-specific protease of poly(ADP-ribose) polymerase (PARP) to an $85-\mathrm{kD}$ fragment both in vivo and in vitro. The enzyme which carries out this cleavage can be blocked by tetrapeptide inhibitors of ICE and is thus presumed to be a cysteine protease. This protease is distinct from ICE (since purified ICE could not cleave PARP) and was called prICE, for protease resembling ICE (93).

Recent studies have suggested that prICE is identical to the CED-3 relative CPP32 (also called Yama or apopain), and that CPP32 is the key protease required for Fas/APO-1-mediated killing. Tewari et al. (94) showed that PARP is cleaved following Fas crosslinking and that purified, activated CPP32 can cleave PARP in a CrmA-inhibitable manner. More direct evidence that prICE is CPP32 came from the biochemical purification of prICE using peptide binding and PARP cleavage as assays (95). CPP32 is produced as a $32 \mathrm{kD}$ proenzyme that is cleaved at two Asp residues to yield the active $\mathrm{p} 17$ and $\mathrm{p} 12$ subunits. Among known cysteine proteases, CPP32 and the $C$. elegans CED-3 protein are most closely related, as might be expected for the mammalian homolog of the nematode cell death protease.

Mice bearing a targeted mutation in the ICE gene have a relative resistance to anti-Fas induced killing, suggesting that ICE itself plays some role in the Fas/APO-1 pathway (96), although several forms of thymocyte death appear to be normally intact in ICE-"knock-out" mice (97). ICE is capable of cleaving CPP32 to its ac- 


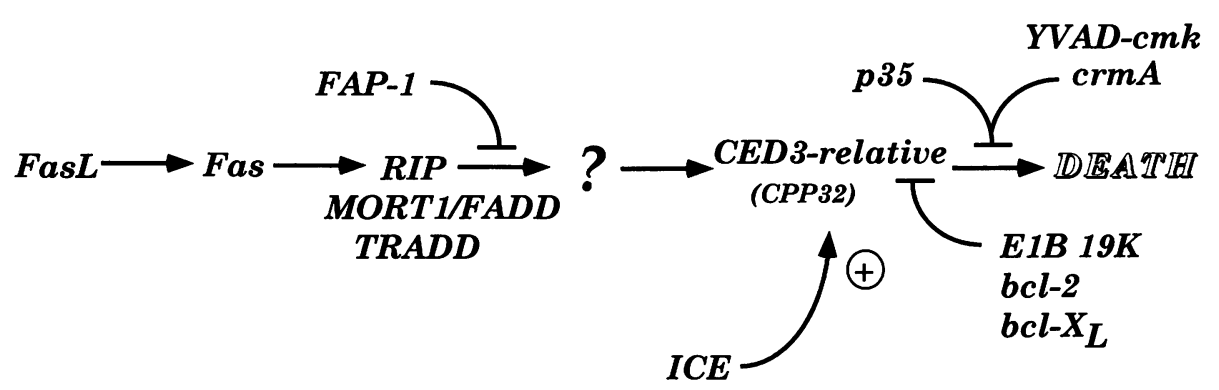

FIG. 2. Model of Fas/ APO-1 signaling See text for details. tive form (94), and thus it may activate CPP32 in vivo. However, osteosarcoma cells containing high levels of active CPP32 have no detectable ICE (95), suggesting that other enzymes are capable of catalyzing cleavage of the CPP32 proenzyme.

\section{OTHER MODULATORS OF FAS/APO-1 SIGNALING}

Another evolutionarily conserved component of cell death regulation involves the Bcl-2 family of membrane proteins, which are capable of forming homo- and hetero-dimers that serve as a "rheostat" to positively or negatively influence cell death decisions (reviewed in Ref. 98). Bcl-2 is homologous to the protein encoded by the ced-9 gene of $C$. elegans (81), which acts as a negative regulator of ced-3-induced cell death (99). Since Fas killing requires a ced-3-like cysteine protease, it has been postulated that $\mathrm{Bcl}-2$ family members also regulate death signals from Fas.

Bcl-2 can partially protect cells from Fas/ APO-1-mediated apoptosis (100), and coexpression of the Bcl-2 binding protein BAG-1 fully protects cells (101). The $\mathrm{Bcl}-2$ relative $\mathrm{Bcl}-\mathrm{X}_{\mathrm{L}}$ is also capable of inhibiting Fas-mediated cell death $(74,102)$. However, the role that Bcl-2 itself plays in modulating Fas signals in vivo is unresolved. Mapara et al. (78) studied the expression of Fas/ APO- 1 and $b c l-2$ in human leukemic B cells activated with Staphylococcus aureus Cowan I (SAC) and interleukin 2 (IL-2). Following activation, cell surface expression of Fas/APO-1 increased, $b c l-2$ mRNA decreased, and cells became susceptible to Fas-mediated killing. However, one cell line did not down-regulate $b c l-2$ in response to SAC plus IL-2 and was paradoxically stimulated to proliferate in response to anti-Fas antibodies. Thus, down-regulation of $b c l-2$ may be permis- sive for induction of apoptosis through Fas/ APO-1. However, there are clearly other means of achieving Fas-resistance, since variability in Fas-responsiveness has been seen despite a uniform absence of Bcl-2 expression in a number of non-hematopoietic tumors (79).

Viruses, in addition to a well-characterized exploitation of mitosis-promoting genes in the viral life cycle, also use anti-apoptotic genes to protect against host cell death (98). The adenovirus E1B 19K protein appears to be encoded by one such gene, and can protect cells from death induced by several stimuli, including TNF (103). E1B 19K can also protect cells from anti-Fas mediated apoptosis (104), presumably as a result of its similarity to Bcl-2 (105). The insect baculovirus p35 protein can inhibit Fas/APO-1-induced apoptosis and PARP cleavage, suggesting that it too may act as a global inhibitor of cell death initiated by many stimuli (106), and is likely to do so by forming a stable complex with members of the ICE/CED-3 family (107). In addition, open reading frames within the EpsteinBarr virus and African Swine Fever virus encode members of the Bcl-2 family (108), and it remains to be determined whether these homologs can protect cells from Fas/APO-1-mediated apoptosis.

Other insights into the regulation of Fas signaling have come from studies of cytotoxic granules proteins. One such protein is TIA-1, an RNA-binding protein that is capable of inducing cell death in permeabilized thymocytes (109); it is phosphorylated by FAST, a serine/threonine kinase that is itself activated by rapid dephosphorylation following Fas ligation (110). FAST may therefore be a substrate of the pro-apoptotic phosphatases described above. Moreover, the TIA-1-related protein TIAR is translocated from the nucleus to the cytoplasm within $30 \mathrm{~min}$ of Fas signaling (111). It is possible that TIA-1, TIAR, and FAST are direct mediators of the Fas 


\section{LIST OF WHO'S WHO:}

\begin{tabular}{|c|c|c|}
\hline FAS & Ligand of Fas/Apo-1 receptor & Activates cell death \\
\hline FAS/Apo-1/ & Transmembrane receptor & Transmits death signal \\
\hline CD95 & Activated by binding of its ligand (FasL) & \\
\hline \multirow[t]{2}{*}{ TNF-Rl } & Tumor necrosis factor receptor type 1 & Transmits death signal \\
\hline & Has homology to Fas/Apo-1 & \\
\hline \multirow[t]{2}{*}{ MORT1/FADD } & "Death domain" containing protein & Candidate signaling component in the Fas- \\
\hline & Interacts with Fas/Apo-1 & mediated death pathway \\
\hline \multirow[t]{3}{*}{ RIP } & Protein kinase & Candidate signaling component in the Fas- \\
\hline & Contains "death domain" & mediated death pathway \\
\hline & Interacts with Fas/Apo-1 & \\
\hline \multirow[t]{2}{*}{ TRADD } & "Death domain" containing protein & Candidate signaling component in the \\
\hline & Interacts with TNF-R 1 & TNF-R1-mediated death pathway \\
\hline \multirow[t]{2}{*}{ Reaper } & Drosophila protein & Necessary and sufficient for cell death in \\
\hline & Has homology to "death domain" & Drosophila development \\
\hline \multirow[t]{2}{*}{ FAP-1 } & Protein phosphatase & Inhibits Fas-mediated signaling pathway \\
\hline & Interacts with Fas/Apo-1 & \\
\hline HCP & $\begin{array}{l}\text { Hematopoietic cell protein tyrosine } \\
\text { phosphatase }\end{array}$ & Promotes Fas-mediated signaling pathway \\
\hline Ras & Oncogene product & $\begin{array}{l}\text { Appears to promote Fas-mediated signaling } \\
\text { pathway }\end{array}$ \\
\hline Ceramide & $\begin{array}{l}\text { Fatty acid intermediate produced by } \\
\text { shingomyelinase }\end{array}$ & $\begin{array}{l}\text { Appears to promote Fas-mediated signaling } \\
\text { pathway }\end{array}$ \\
\hline \multirow[t]{2}{*}{ CED-3 } & C. elegans gene product & Promotes cell death in $C$. elegans development \\
\hline & Resembles mammalian ICE protein & \\
\hline \multirow[t]{3}{*}{ ICE } & $\begin{array}{l}\text { Mammalian interleukin } 1 \beta \text {-converting } \\
\text { enzyme, related to } C \text {. Elegans Ced-3 } \\
\text { gene product }\end{array}$ & May play role in Fas-mediated death pathway \\
\hline & $\begin{array}{l}\text { Cyteine protease that cleaves after Asp } \\
\text { residues }\end{array}$ & \\
\hline & $\begin{array}{l}\text { May cleave and activate related cysteine } \\
\text { protease CPP } 32\end{array}$ & \\
\hline Nedd2/ICH-1 & Cysteine protease of the ICE family & \\
\hline ICH-2 & Cysteine protease of the ICE family & \\
\hline CPP32/prICE/ & Cysteine protease of the ICE family & Key protease in Fas-mediated death pathway \\
\hline Yama/Apopain & Cleaves PARP & \\
\hline \multirow[t]{3}{*}{ PARP } & Poly(ADP-ribose)polymerase & \\
\hline & Substrate of CPP32 protease & \\
\hline & Cleaved during apoptosis & \\
\hline \multirow{3}{*}{$\begin{array}{r}\text { Fragmentin } 2 / \\
\text { GranzymeB }\end{array}$} & Cytotoxic granule protein & Promotes cell death \\
\hline & Protease with Asp specificity & \\
\hline & Causes cleavage of CPP32 & \\
\hline \multirow[t]{2}{*}{ CrmA } & Cowpox encoded ICE-inhibitor & Inhibits Fas-mediated death pathway \\
\hline & Inhibits PARP cleavage & \\
\hline \multirow[t]{2}{*}{ CED-9 } & C. elegans gene product & Inhibits cell death \\
\hline & Negative regulator of Ced-3 & \\
\hline \multirow[t]{2}{*}{ Bcl-2 } & Mammalian homolog of Ced-9 & Partially protects cells from Fas-mediated apoptosis \\
\hline & "Rheostat" control of cell death & \\
\hline BAG-1 & Binds to Bcl-2 & $\begin{array}{l}\text { With Bcl-2, protects cells from Fas-mediated } \\
\text { apoptosis }\end{array}$ \\
\hline $\mathrm{Bcl}-\mathrm{X}_{\mathrm{L}}$ & Protein related to $\mathrm{Bcl}-2$ & Protects cells from Fas-mediated apoptosis \\
\hline E1B $19 \mathrm{~K}$ & Adenovirus protein similar to $\mathrm{Bcl}-2$ & Protects cells from Fas-mediated apoptosis \\
\hline \multirow[t]{2}{*}{ p35 } & Insect baculovirus protein & Protects cells from Fas-mediated apoptosis \\
\hline & $\begin{array}{l}\text { Forms stable complex with CED-3 } \\
\text { family members }\end{array}$ & \\
\hline
\end{tabular}


signal transduction cascade; at the very least, the behavior of these proteins make them interesting markers of Fas signaling events.

Finally, as mentioned above, the nature and degree of T- and B-cell activation can modulate cellular responses to Fas/APO-1. While the Bcl-2 "rheostat" may control part of the response, most of the signals controlling the decision are unknown. Identification of other molecules whose activity or subcellular localization changes with anti-Fas treatment will provide a panel of candidates that can be tested for their ability to modulate the Fas/APO-1 signal.

\section{IS THERE A COMMON SIGNALING PATHWAY FOR FAS/APO-1 AND TNF-R1?}

The extent to which the Fas/APO-1 and TNF-R 1 pathways overlap remains an open question. There are several similarities between signals generated by anti-Fas and TNF. Cell deaths caused by these treatments occur with indistinguishable kinetics and morphology, a similarity which accounts for the initial proposal that TNF's cytotoxicity is mediated by Fas (7). Other studies have shown that cell death signaled by both Fas/ APO- 1 and TNF-R 1 can be blocked by a number of proteins, including Bcl-2 (100), Bcl- $\mathrm{X}_{\mathrm{L}}$ (74), p35 (106), E1B 19K protein (104), and the ICE inhibitor CrmA (90).

However, several pieces of evidence argue against a shared pathway. Chimeric proteins consisting of the extracellular domain of CD40 fused to the cytoplasmic domain of either Fas/ APO- 1 or TNF-R 1 are both capable of inducing cell death in the presence of the ligand gp39 (as can the cytoplasmically unrelated TNF-R2), but these chimeras kill with different kinetics (40). Moreover, conditions have been described under which cell death via Fas/APO-1 can be inhibited while cell death via TNF-R1 is unaffected $(63,112)$.

At the very least, TNF-Rl signaling is likely to have several cellular effects, such as NF $\kappa \mathrm{B}$ activation, that are not shared by Fas. It is possible that FAS/APO-1 and TNF-R share elements of the same pathway, but engage them with different efficiency. For example, the affinity of Fas/APO-1 or TNF-R1 for a potent death-inducing intermediate may differ. Alternatively, regions outside the death domain may modify the strength of the apoptotic signal; the inhibitory $\mathrm{C}$ terminus of Fas is an example of such a modifier domain.

\section{CONCLUSIONS}

The Fas/APO-1 receptor plays a central role in mammalian tolerance to self-antigen and cellmediated cytotoxicity. Over the past year, several studies have elucidated aspects of Fas/APO-1 signaling which make it possible to draw a speculative model for the Fas/APO-1 pathway (Fig. 2). Following ligand binding, receptor signals are first generated by the aggregation of the Fas death domain. A number of cytoplasmic death domain-containing proteins have been identified which may associate with Fas to form a signaling-competent complex; phosphorylation and dephosphorylation events modulate signals transmitted by the active complex. Further downstream, signals engage a member of the CED-3 family of cysteine proteases, possibly the CPP32 protease; a number of cellular and viral proteins are able to block cell death at this point. It is still unknown whether the protease itself catalyzes all additional reactions necessary for cell death or whether it activates additional signaling intermediates.

By analogy with the signaling processes governing proliferation and differentiation, the signal for programmed cell death seem to converge on an evolutionarily conserved set of reactions. Thus, the details of programmed cell death regulation in other organisms are relevant to Fas/ APO-1 signaling. Many unresolved issues remain: (i) which, if any, of the known Fasinteracting proteins are used to transduce Fas/ APO-1 signals, and how does signal modification occur, (ii) how do these signals lead to the activation of the protease, and (iii) how does the protease induce cell death? Answers to these questions will permit not only a better understanding of this basic biological process, but also the prospect of developing therapeutic agents for those conditions in which programmed cell death plays a role.

\section{REFERENCES}

1. Saunders JW. (1966) Death in embryonic systems. Science 154: 604-612.

2. Wyllie AH, Kerr JFR, Currie AR. (1980) Cell death: The significance of apoptosis. Int. Rev. Cytol. 68: 251-306. 
3. Ellis HM, Horvitz HR. (1986) Genetic control of programmed cell death in the nematode C. elegans. Cell 44: 817-829.

4. Abrams JM, White K, Fessler LI, Steller H. (1993) Programmed cell death during Drosophila embryogenesis. Development 117: $29-43$.

5. Raff M. (1992) Social controls on cell survival and cell death. Nature 356: 397-400.

6. Trauth BC, Klas C, Peters AMJ, et al. (1989) Monoclonal antibody-mediated tumor regression by induction of apoptosis. Science 245: 301-305.

7. Yonehara S, Ishii A, Yonehara M. (1989) A cell-killing monoclonal antibody (anti-Fas) to a cell surface antigen co-downregulated with the receptor of tumor necrosis factor. J. Exp. Med. 169: 1747-1756.

8. Itoh N, Yonehara S, Ishii A, et al. (1991) The polypeptide encoded by the cDNA for human cell surface antigen Fas can mediate apoptosis. Cell 66: 233-243.

9. Oehm A, Behrmann I, Falk W, et al. (1992) Purification and molecular cloning of the APO-1 cell surface antigen, a member of the tumor necrosis factor/nerve growth factor receptor superfamily. J. Biol. Chem. 267: 10709-10715.

10. Smith CA, Farrah T, Goodwin RG. (1994) The TNF receptor superfamily of cellular and viral proteins: Activation, costimulation, and death. Cell 76: 959-962.

11. Watanabe-Fukunaga R, Brannan CI, Copeland NG, Jenkins NA, Nagata S. (1992b) Lymphoproliferation disorder in mice explained by defects in Fas antigen that mediates apoptosis. Nature 356: 314317.

12. Suda T, Takahashi $T$, Golstein $P$, Nagata $S$. (1993) Molecular cloning and expression of the Fas ligand, a novel member of the tumor necrosis factor family. Cell 75: $1169-$ 1178.

13. Takahashi T, Tanaka M, Brannan CI, et al. (1994) Generalized lymphoproliferative disease in mice caused by a point mutation in the Fas ligand. Cell 76: 969-976.

14. Lynch DH, Watson ML, Alderson MR, et al. (1994) The mouse Fas-ligand gene is mutated in gld mice and is part of a TNF family gene cluster. Immunity 1: 131-136.

15. Ashwell JD, Cunningham RE, Noguchi PD, Hernandez D. (1987) Cell growth cycle block of $\mathrm{T}$ cell hybridomas upon activation with antigen. J. Exp. Med. 165: 173-194.
16. Singer GG, Abbas AK. (1994) The Fas antigen is involved in peripheral but not thymic deletion of $\mathrm{T}$ lymphocytes in $\mathrm{T}$ cell receptor transgenic mice. Immunity 1: 365-371.

17. Russell JH, Rush B, Weaver C, Wang R. (1993) Mature T cells of autoimmune lpr/ $l p r$ mice have a defect in antigen-stimulated suicide. Proc. Natl. Acad. Sci. U.S.A. 90: 4409-4413.

18. Dhein J, Walczak H, Baumler C, Debatin K-M, Krammer PH. (1995) Autocrine T-cell suicide by APO-1/(Fas/CD95). Nature 373: 438-441.

19. Brunner $\mathrm{T}$, Mogil RJ, LaFace $\mathrm{D}$, et al. (1995) Cell-autonomous Fas (CD95)/Fasligand interaction mediates activation-induced apoptosis in T-cell hybridomas. $\mathrm{Na}$ ture 373: 441-444.

20. Ju S-T, Panka DJ, Cui H, et al. (1995) Fas(CD95)/FasL interactions required for programmed cell death after T-cell activation. Nature 373: 444-448.

21. Rothstein TL, Wang JKM, Panka DJ, et al. (1995) Protection against Fas-dependent Th1-mediated apoptosis by antigen receptor engagement in B cells. Nature 374: 163 165.

22. Rathmell JC, Cooke MP, Ho WY, et al. (1995) CD95(Fas)-dependent elimination of self-reactive $\mathrm{B}$ cells upon interaction with $\mathrm{CD} 4^{+}$cells. Nature 376: 181-184.

23. Cohen PL, Eisenberg RA. (1991) Lpr and gld: Single gene models of systemic autoimmunity and lymphoproliferative disease. Annu. Rev. Immunol. 9: 243-269.

24. Henkart PA. (1994) Lymphocyte-mediated cytotoxicity: Two pathways and multiple effector molecules. Immunity 1: 343-346.

25. Ogasawara J, Watanabe-Fukunaga R, Adachi $M$, et al. (1993) Lethal effect of the anti-Fas antibody in mice. Nature 364: 806809.

26. Adachi $M$, Suematsu $S$, Kondo $T$, et al. (1995) Targeted mutation in the Fas gene causes hyperplasia of peripheral lymphoid organs and liver. Nature Genet. 11: 294-300.

27. Leist M, Gantner F, Kunstle G, et al. (1996) The $55-\mathrm{kD}$ tumor necrosis factor receptor and CD95 independently signal murine hepatocyte apoptosis and subsequent liver failure. Mol. Med. 2: 109-124.

28. Cheng J, Zhou T, Liu C, et al. (1994) Protection from Fas-mediated apoptosis by a soluble form of the Fas molecule. Science 263: 1759-1762. 
29. Fisher GH, Rosenberg FJ, Straus SE, et al. (1995) Dominant interfering Fas gene mutations impair apoptosis in a human autoimmune lymphoproliferative syndrome. Cell 81: 935-946.

30. Rieux-Laucat F, Le Deist F, Hivroz C, et al. (1995) Mutations in Fas associated with human lymphoproliferative syndrome and autoimmunity. Science 268: 1347-1349.

31. Bellgrau D, Gold D, Selawry H, Moore J, Franzusoff A, Duke RC. (1995) A role for CD95 ligand in preventing graft rejection. Nature 377: 630-632.

32. Groux H, Torpier G, Monte D, Mouton Y, Capron A, Ameisen JC. (1992) Activationinduced death by apoptosis in $\mathrm{CD}^{+} \mathrm{T}$ cells from human immunodeficiency virus-infected asymptomatic individuals. J. Exp. Med. 175: 331-340.

33. Katsikis PD, Wunderlich ES, Smith CA, Herzenberg LA, Herzenberg LA. (1995) Fas antigen stimulation induces marked apoptosis of T lymphocytes in human immunodeficiency virus-infected individuals. J. Exp. Med. 181: 2029-2036.

34. Westendorp MO, Frank R, Ochsenbauer C, et al. (1995) Sensitization of $\mathrm{T}$ cells to CD95-mediated apoptosis by HIV-1 Tat and gp120. Nature 375: 497-500.

35. Itoh N, Nagata S. (1993) A novel protein domain required for apoptosis. J. Biol. Chem. 268: 10932-10937.

36. Tartaglia LA, Ayres TM, Wong GHW, Goeddel DV. (1993b) A novel domain within the $55 \mathrm{kd}$ TNF receptor signals cell death. Cell 74: 845-853.

37. Schlessinger J. (1988) Signal transduction by allosteric receptor oligomerization. Trends Biochem. Sci. 13: 443-447.

38. Dhein J, Daniel PT, Trauth BC, Oehm A, Moller P, Krammer PH. (1992) Induction of apoptosis by monoclonal antibody antiAPO-1 class switch variants is dependent on cross-linking of APO-1 cell surface antigens. J. Immunol. 149: 3166-3173.

39. Banner DW, D'Arcy A, Janes W, et al. (1993) Crystal structure of the soluble human $55 \mathrm{kd}$ TNF receptor-human TNF $\beta$ complex: implications for TNF receptor activation. Cell 73: 431-445.

40. Clement $M-V$, Stamenkovic I. (1994) Fas and tumor necrosis factor receptor-mediated cell death: Similarities and distinctions. J. Exp. Med. 180: 557-567.

41. Bazzoni F, Alejos E, Beutler B. (1995) Chi- meric tumor necrosis factor receptors with constitutive signaling activity. Proc. Natl. Acad. Sci. U.S.A. 92: 5376-5380.

42. Fields S, Song O. (1989) A novel genetic system to detect protein-protein interactions. Nature 340: 245-246.

43. Boldin MP, Mett IL, Varfolomeev EE, et al. (1995a) Self-association of the "death domains" of the p55 tumor necrosis factor (TNF) receptor and Fas/APOl prompts signaling for TNF and Fas/APOl effects. J. Biol. Chem. 270: 387-391.

44. Stanger BZ, Leder $P$, Lee T-H, Kim E, Seed B. (1995) RIP: A novel protein containing a death domain that interacts with Fas/ APO-1 (CD95) in yeast and causes cell death. Cell 81: 513-523.

45. Song HY, Dunbar JD, Donner DB. (1994) Aggregation of the intracellular domain of the type 1 tumor necrosis factor receptor defined by the two-hybrid system. J. Biol. Chem. 269: 22492-22495.

46. Hsu H, Xiong J, Goeddel DV. (1995) The TNF receptor 1 -associated protein TRADD signals cell death and NF- $\kappa \mathrm{B}$ activation. Cell 81: 495-504.

47. Boldin MP, Varfolomeev EE, Pancer Z, Mett IL, Camonis JH, Wallach D. (1995b) A novel protein that interacts with the death domain of Fas/APOl contains a sequence motif related to the death domain. J. Biol. Chem. 270: 7795-7798.

48. Chinnaiyan AM, O'Rourke $K$, Tewari M, Dixit VM. (1995) FADD, a novel death domain-containing protein, interacts with the death domain of Fas and initiates apoptosis. Cell 81: 505-512.

49. Golstein P, Marguet D, Depraetere V. (1995) Homology between Reaper and the cell death domains of Fas and TNFR1. Cell 81: 185-186.

50. White K, Grether ME, Abrams JM, Young L, Farrell K, Steller H. (1994) Genetic control of programmed cell death in Drosophila. Science 264: 677-693.

51. Cleveland JL, Ihle JN. (1995) Contenders in FasL/TNF death signaling. Cell 81: 479-482.

52. Schulze-Osthoff $\mathrm{K}$, Walczak $\mathrm{H}$, Droge W, Krammer PH. (1994b) Cell nucleus and DNA fragmentation are not required for apoptosis. J. Cell. Biol. 127: 15-20.

53. Nakajima H, Golstein P, Henkart PA. (1995) The target cell nucleus is not required for cell-mediated granzyme- or Fas-based cytotoxicity. J. Exp. Med. 181: 1905-1909. 
54. Owen-Schaub LB, Yonehara S, Crump WLd, Grimm EA. (1992) DNA fragmentation and cell death is selectively triggered in activated human lymphocytes by Fas antigen engagement. Cell. Immunol. 140: 197205.

55. Klas C, Debatin K-M, Jonker RR, Krammer PH. (1993) Activation interferes with the APO-1 pathway in mature human $\mathrm{T}$ cells. Int. Immunol. 5: 625-630.

56. Heldin C-H. (1995) Dimerization of cell surface receptors in signal transduction. Cell 80: 213-223.

57. Kolesnick R, Golde DW. (1994) The sphingomyelin pathway in tumor necrosis factor and interleukin-1 signaling. Cell 77: 325328.

58. Kyriakis JM, Banerjee P, Nikolakaki E, et al. (1994) The stress-activated protein kinase subfamily of c-Jun kinases. Nature 369: 156-160.

59. Derijard B, Hibi M, Wu IH, et al. (1994) JNK1: A protein kinase stimulated by UV light and Ha-Ras that binds and phosphorylates the c-Jun activation domain. Cell 76: 1025-1037.

60. Darnay BG, Reddy SAG, Aggarwal BB. (1994a) Identification of a protein kinase associated with the cytoplasmic domain of the p60 tumor necrosis factor receptor. $J$. Biol. Chem. 269: 20299-20304.

61. Darnay BG, Singh S, Chaturvedi MM, Aggarwal BB. (1995) The p60 tumor necrosis factor (TNF) receptor-associated kinase (TRAK) binds residues 344-397 within the cytoplasmic domain involved in TNF signaling. J. Biol. Chem. 270: 14867-14870.

62. Eischen CM, Dick CJ, Leibson PJ. (1994) Tyrosine kinase activation provides an early and requisite signal for Fas-induced apoptosis. J. Immunol. 153: 1947-1954.

63. Schulze-Osthoff K, Krammer PH, Droge W. (1994a) Divergent signalling via APO-1/Fas and the TNF receptor, two homologous molecules involved in physiological cell death. EMBO J. 13: 4587-4596.

64. Sato T, Irie S, Kitada S, Reed JC. (1995) FAP-1: A protein tyrosine phosphatase that associates with Fas. Science 268: 411-415.

65. Feng X-H, Zhao Y, Bottino PJ, Kung S-D. (1993) Cloning and characterization of a novel member of protein kinase family from soybean. Biochim. Biophys. Acta 1172: 200-204.

66. Hubbard SR, Wei L, Ellis L, Hendrickson
WA. (1994) Crystal structure of the tyrosine kinase domain of the human insulin receptor. Nature 372: 746-754.

67. Maekawa $K$, Imagawa N, Nagamatsu $M$, Harada S. (1994) Molecular cloning of a novel protein-tyrosine phosphatase containing a membrane-binding domain and GLGF repeats. FEBS Lett. 337: 200-206.

68. Su X, Zhou T, Wang Z, Yang P, Jope RS, Mountz JD. (1995) Defective expression of hematopoietic cell protein tyrosine phosphatase (HCP) in lymphoid cells blocks Fasmediated apoptosis. Immunity 2: 353-362.

69. Shultz LD, Schweitzer PA, Rajan TV, et al. (1993) Mutations at the murine motheaten locus are within the hematopoietic cell protein-tyrosine phosphatase (Hcph) gene. Cell 73: 1445-1454.

70. Cifone MG, R DeMaria, Roncaioli $P$, et al. (1994) Apoptotic signaling through CD95 (Fas/Apo-1) activates an acidic sphingomyelinase. J. Exp. Med. 180: 1547-1552.

71. Gill BM, Nishikata H, Chan D, Delovitch TL, Ochi A. (1994) Fas antigen and sphingomyelin-ceramide turnover-mediated signaling: role in life and death of $\mathrm{T}$ lymphocytes. Immunol. Rev. 142: 113-126.

72. Obeid LM, Linardic CM, Karolak LA, Hannun Y. (1993) Programmed cell death induced by ceramide. Science 259: 17691771.

73. Jarvis WD, Kolesnick RN, Fornari FA, Traylor RS, Gewirtz DA, Grant S. (1994) Induction of apoptotic DNA damage and cell death by activation of the sphingomyelin pathway. Proc. Natl. Acad. Sci. U.S.A. 91: 7377.

74. Jaattela $M$, Benedict $M$, Tewari $M$, Shayman JA, Dixit VM. (1995) Bcl-x and Bcl-2 inhibit TNF and Fas-induced apoptosis and activation of phospholipase $\mathrm{A} 2$ in breast carcinoma cells. Oncogene 10: 2297-2305.

75. Gulbins E, Bissonnette R, Mahboubi A, et al. (1995) Fas-induced apoptosis is mediated via a ceramide-initiated RAS signaling pathway. Immunity 2: 341-351.

76. Liu J, Mathias S, Yang Z, Kolesnick RN. (1994) Renaturation and tumor necrosis factor- $\alpha$ stimulation of a $97-\mathrm{kDa}$ ceramideactivated protein kinase. J. Biol. Chem. 269: 3047-3052.

77. Alderson MR, Armitage RJ, Maraskovsky E, et al. (1993) Fas transduces activation signals in normal human $\mathrm{T}$ lymphocytes. $J$. Exp. Med. 178: 2231-2235. 
78. Mapara MY, Bargou R, Zugck C, et al. (1993) APO-1 mediated apoptosis or proliferation in human chronic B lymphocytic leukemia: Correlation with $b c l-2$ oncogene expression. Eur. J. Immunol. 23: 702-708.

79. Owen-Schaub LB, Radinsky R, Kruzel E, Berry K, Yonehara S. (1994) Anti-Fas on nonhematopoietic tumors: Levels of Fas/ APO-1 and $b c l-2$ are not predictive of biological responsiveness. Cancer Res. 54: 1580-1586.

80. Aggarwal BB, Singh S, Lapushin R, Totpal K. (1995) Fas antigen signals proliferation of normal human diploid fibroblasts and its mechanism is different from tumor necrosis factor receptor. FEBS Lett. 364: 5-8.

81. Hengartner MO, Horvitz HR. (1994) C. elegans cell survival gene ced-9 encodes a functional homolog of the mammalian proto-oncogene bcl-2. Cell 76: 665-676.

82. Vaux DL, Haecker G, Strasser A. (1994) An evolutionary perspective on apoptosis. Cell 76: 777-779.

83. Yuan J, Shaham S, Ledoux S, Ellis HM, Horvitz HR. (1993) The C. elegans cell death gene ced-3 encodes a protein similar to mammalian interleukin- $1 \beta$-converting enzyme. Cell 75: 641-652.

84. Thornberry NA, Bull HG, Calaycay JR, et al. (1992) A novel heterodimeric cysteine protease is required for interleukin- $1 \beta$ processing in monocytes. Nature 356: 768-774.

85. Martin SJ, Green DR. (1995) Protease activation during apoptosis-Death by a thousand cuts. Cell 82: 349-352.

86. Miura M, Zhu H, Rotello R, Hartwieg EA, Yuan J. (1993) Induction of apoptosis in fibroblasts by IL- $1 \beta$-converting enzyme, a mammalian homolog of the $C$. elegans cell death gene ced-3. Cell 75: 653-660.

87. Shi L, Kam C-M, Powers JC, Aebersold R, Greenberg AH. (1992b) Purification of three cytotoxic lymphocyte granule serine proteases that induce apoptosis through distinct substrate and target cell interactions. J. Exp. Med. 176: 1521-1529.

88. Shi L, Kraut RP, Aebersold R, Greenberg AH. (1992a) A natural killer cell granule protein that induces DNA fragmentation and apoptosis. J. Exp. Med. 175: 553-566.

89. Darmon AJ, Nicholson DW, Bleackley RC. (1995) Activation of the apoptotic protease CPP32 by cytotoxic T-cell-derived granzyme B. Nature 377: 446-448.

90. Tewari M, Dixit VM. (1995) Fas- and tumor necrosis factor-induced apoptosis is inhibited by the poxvirus $\mathrm{crm} A$ gene product. $J$. Biol. Chem. 270: 3255-3260.

91. Enari M, Hug H, Nagata S. (1995) Involvement of an ICE-like protease in Fas-mediated apoptosis. Nature 375: 78-81.

92. Los M, Van de Craen M, Penning LC, et al. (1995) Requirement of an ICE/CED-3 protease for Fas/APO-1 mediated apoptosis. Nature 375: 81-83.

93. Lazebnik YA, Kaufmann SH, Desnoyers S, Poirier GG, Earnshaw WC. (1994) Cleavage of poly (ADP-ribose) polymerase by a proteinase with porperties like ICE. Nature 371: 346-347.

94. Tewari M, Quan LT, O'Rourke K, et al. (1995) Yama/CPP32b, a mammalian homolog of CED-3, is a CrmA-inhibitable protease that cleaves the death substrate poly(ADP-ribose) polymerase. Cell 81: 801-809.

95. Nicholson DW, Ali A, Thornberry NA, et al. (1995) Identification and inhibition of the ICE/CED-3 protease necessary for mammalian apoptosis. Nature 376: 37-43.

96. Kuida K, Lippke JA, Ku G, et al. (1995) Altered cytokine export and apoptosis in mice deficient in interleukin-1-beta converting enzyme. Science 267: 2000-2003.

97. Li P, Allen H, Banerjee S, et al. (1995) Mice deficient in IL-1-beta-converting enzyme are defective in production of mature IL-1 beta and resistant to endotoxic shock. Cell 80: $401-411$.

98. Oltvai ZN, Korsmeyer SJ. (1994) Checkpoints of dueling dimers foil death wishes. Cell 79: 189-192.

99. Hengartner MO, Ellis RE, Horvitz HR. (1992) Caenorhabditis elegans gene ced-9 protects cells from programmed cell death. $\mathrm{Na}$ ture 356: 494-499.

100. Itoh N, Tsujimoto Y, Nagata S. (1993) Effect of $b c l-2$ on Fas antigen-mediated cell death. J. Immunol. 151: 621-627.

101. Takayama S, Sato T, Krajewski S, et al. (1995) Cloning and functional analysis of BAG-1: A novel Bcl-2-binding protein with anti-cell death activity. Cell 80: 279284.

102. Boise LH, Minn AJ, Noel PJ, et al. (1995) CD28 costimulation can promote $\mathrm{T}$ cell survival by enhancing the expression of $\mathrm{Bcl}-$ XL. Immunity 3: 87-98.

103. White E, Sabbatini P, Debbas M, Wold WSM, Kusher DI, Gooding LR. (1992) The 19-kilodalton Adenovirus E1B transform- 
ing protein inhibits programmed cell death and prevents cytolysis by tumor necrosis factor $\alpha$. Mol. Cell. Biol. 12: 2570-2580.

104. Hashimoto S, Ishii A, Yonehara S. (1991) The Elb oncogene of adenovirus confers cellular resistance to cytotoxicity of tumor necrosis factor and monoclonal anti-Fas antibody. Int. Immunol. 3: 343-351.

105. Chiou S-K, Tseng C-C, Rao L, White E. (1994) Functional complementation of the Adenovirus E1B 19-kilodalton protein with Bcl-2 in the inhibition of apoptosis in infected cells. J. Virol. 68: 6553-6566.

106. Beidler DR, Tewari M, Friesen PD, Poirier G, Dixit VM. (1995) The baculovirus p35 protein inhibits Fas- and tumor necrosis factor-induced apoptosis. J. Biol. Chem. 270: 16526-16528.

107. Bump NJ, Hackett $M$, Hugunin $M$, et al. (1995) Inhibition of ICE family proteases by baculovirus antiapoptotic protein p35. Science 269: 1885-1888.

108. Williams GT, Smith CA. (1993) Molecular regulation of apoptosis: Genetic controls on cell death. Cell 74: 777-779.

109. Tian Q, Streuli M, Saito H, Schlossman SF, Anderson P. (1991) A polyadenylate binding protein localized to the granules of cytolytic lymphocytes induces DNA fragmentation in target cells. Cell 67: 629-639.

110. Tian Q, Taupin J-L, Elledge S, Robertson M, Anderson P. (1995) Fas-activated serine/ threonine kinase (FAST) phosphorylates TIA-1 during Fas-mediated apoptosis. $J$. Exp. Med. 182: 865-874.

111. Taupin J-L, Tian Q, Kedersha N, Robertson M, Anderson P. (1995) The RNA-binding protein TIAR is translocated from the nucleus to the cytoplasm during Fas-mediated apoptotic cell death. Proc. Natl. Acad. Sci. U.S.A. 92: 1629-1633.

112. Wong GHW, Goeddel DV. (1994) Fas antigen and p55 TNF receptor signal apoptosis through distinct pathways. J. Immunol. 152: 1751-1755.

Contributed by P. Leder on October 12, 1995. 